\title{
Management of Public Relation Efforts in Public Interest
}

\author{
Devi Diana Hasna \\ Department of Education Management \\ Universitas Negeri Surabaya \\ Surabaya, Indonesia \\ Devi.17070845013@mhs.unesa.ac.id
}

\begin{abstract}
The growth of public interest implies urgency to the growing institution in order to respond the challenges and needs of the public so that the public will determine the choice of which institutions deserve to be given the trust to educate. Their relationship with the public schools is going to produce a conducive communication and leads to meeting the needs of both. The purpose of this research is done to identify, describe, and explain the planning, organization, implementation, and evaluation of the factors affecting public relations in an effort to attract people in school with qualitative research approach. Data collection technique is a semi-structured interview, observation, and documentation. The data in this study in the form of written documents, photographs, important documents and interviews related to the title while the data source is the subject of study as informants in this study are: 1) Principal; 2) Vice Principal Public Relations; 3) the School Committee; 4) Public. Data analysis techniques used in this research is qualitative descriptive technique.
\end{abstract}

Keywords—public relations; management; the public interest

\section{INTRODUCTION}

Humans are the subject of education, and as an object of education, because those humans have the attitude to be educated and educate, however, the success of these efforts depends largely on whether the purpose is clear. According to Aristotle, the purpose of education should be formulated in accordance with the objectives of the establishment of a country [1]. Therefore, it can take an understanding that the value of education can be seen from the existing educational purposes.

The state of society can be measure through education. Therefore, dilapidation society will not be repaired in any way except by education, according Plato. The rapid advancement of the development of society presupposed by the growing public demand for the development of educational institutions, so that it is possible for the institution that can not acomodation demands of society will have an impact on exclusion institution or die along with waning interest.

Educational institutions and the public is not just a relationship, but rather the meaning of communication and breadth of this will have an impact on the harmonization of school and public relations. In addition to the need for effective communication given that the nation we live in has a lot of culture. " In this global multicultural era, to be able to establish effective communication requires social and cultural sustainability that is obtained by the perpetrators of public relations with stakeholders [2]. In other words, the relationship of the school with the public will bear fruit in the form of cooperation, and such cooperation can be implemented properly in the event of communication conducive and leads to meeting the needs of both." School become the main point for the surrounding environment, so the development and planning must be based on environmental concepts that involve the participation of the related environment." [3].

Constraints faced by Al-Aziziyah junior high school the case studies in this research is a common problem that is often faced by the school, it is proved by some researchers observed results in some schools especially private around junior high school Al-Aziziyah. Often, school and public relations more to the pattern of one-way relationship, the willingness of schools to meet the needs of the public on matters relating to the school which makes the students as adults that are beneficial to life and for society in general. "One of the functions of strategic management on achieving organizational goals and objectives is often interpreted as public relations [4]. With such demands would be a burden for the school, with all its limitations. This means that the school less get feedback from the public, so this research is in need to be examined in order to find a treatment or a good public relationship management.

Urgency of this study also shape efforts to prove their relevance or management relationship society which implies the junior high school Al-Aziziyah these will then be proved by the comparative study, a comparison of the state of school before applying the management of public relations with the state or school results after applying management PR school. Researchers also will take the focus on the factors that affect the management of public relations. The shape of a person's interest is influenced by environmental background, economic level, social status, and experience. Interest a person can develop as a result of physical and social changes in society [5].

The general objective of the holding of research based on the problems found knows how to manage public relations conducted junior high school Al-Aziziyah Sidoarjo increase public interest. Support in analyzing, describing the picture of the public relationship management at Al-Aziziyah sidoarjo 
junior high school writer uses management function based on the theory of George Terry namely Planning, Organizing, Actuating, and Controlling. which defines management in his book Principles of Management, namely "A process that set for the planning, organizing, and monitoring by utilizing both a science and an art achieve predetermined objectives". [6]

A management is successful if all four functions above can be carried out. Weakness on one management function will affect the overall management and lead to failure to achieve an effective and efficient process.

\section{METHOD}

The research method is qualitative research approachment in the mix with the approach based on the evaluation of public relations management in this study used before - after (before and after) the management of public relations in the public interest. Pre-Posttest. According of this research can be described as follows [7].

The design of this study using case studies in qualitative research generally aims to maintain the integrity of the object under study [7]. This research was conducted in the junior high school Al-Aziziyah Sidoarjo. Precisely on the road kedungpeluk Rt $01 \mathrm{Rw} 03$ No. 3 Kebonsari village temple subdistrict, Sidoarjo. In the qualitative study researcher role as a key instrument so that researchers should always be present in the field and in direct contact with the object to obtain the necessary data in the study. Before conducting the study, the researchers conduct a preliminary study, after that can determine the time of the research plan. The time duration for the research plan will be approximately one to two months of implementation research. In this study the presence of researchers scheduled according to demand a place to study

Test the validity of the data in this study using techniques such as: (1) credibility, (2) transferability, (3) dependability, and (4) confirmability.

\section{RESULTS AND DISCUSSION}

Planning public relations in an effort to attract people in the junior high school Al-Aziziyah Sidoarjo. Steps taken in planning the meetings, analyze problems and needs, determine the form of formulation strategies / policies in the last sollution and formulate media and techniques without forgetting the budget that is required in each program such public relations activities. It is justified in planning theory by Gibson, et al (1982) which includes planning activities and tools to set goals appropriate to achieve the objectives that have been determined [5].

Constraints on the face as well as lack of follow sertaan some educators in meeting planning solutions to the school is to maximize the role of educators who participated in the planning of public relations at the school this is done in accordance with the theory Siagian, notion of management is a process mobilize others to obtain a certain result in the achievement of predetermined objectives [6].

Organizing public relations in an effort to attract people in the junior high school Al-Aziziyah Sidoarjo. The process of organizing in Al-Aziziyah junior high school covers the basic steps in organizing programs or public relations activities in educational institutions.

Among others at the start of the decisive tasks, time parameters and needs, positions and responsibilities, detailing the relationship of authority, supervisory relationships and communication links. This is supported by the theory of the basic steps in organizing Gorton is to determine the tasks, time parameters and needs, positions and responsibilities, detailing the relationship of authority, supervisory relationships, communication links [8].

Organizing is not spared by good coordination. Coordinatio means keeping each task that has been given the authority and responsibility be done in accordance with the rules in achieving the goals that have been communicated together. It thus supported the theory coordination is a series of activities to connect, integrate, and align people and jobs. [9]

Implementation of public relations in an effort to attract people in the junior high school Al-Aziziyah Sidoarjo.

Implementation of activities or programs of public relations. Al-Aziziyah junior high school to build relationships inside and outside of this consists of two, namely: (1) the implementation of activities or internal public relations program and (2) the implementation of activities or external public relations program.

The process of implementation of the supervision by the principal and foundation leaders directly in its implementation. supervision of the school and the foundation. Form of supervision is usually monitored by the licensing agreement in handing the sponsorship facilities at primary schools around the school. It is supported by theory According to Johnson, 15 points out, the supervisor is a function of the system to make adjustments to the plan, arranged for the purpose of system deviations only within the limits that can tolerant [10].

Evaluation of public relations in an effort to attract people in the junior high school Al-Aziziyah Sidoarjo.The evaluation process of public relations at the school is done through two stages, summative and formative evaluation. Evaluations were performed at implementation public relations activities and programs itself to equate the implementation planning activities or programs that are made together. While the formative evaluation conducted when the execution has been completed by looking at the activity report or program by comparing it with the checklist there.

Based on a description of the management of public relations that have been in explore, investigators assessed in addition to improve management of public relations at the school, preferably the relationship that occurs not only in one direction or from the school to the public, because of the results of research in the junior high school Al-Aziziyah role of parents is very minimal, Parents Take the important role for all role in the world such as educators, volunteers, decision makers, and a team member working with teachers at the school". [11] 
Moreover those are supposed to be implemented right as well to create a mutualistic relationship or mutual benefit. Such as Factors affecting the public interest in the junior high school Al-Aziziyah Sidoarjo. Public relations are a group of people concerned with all things being equal, interest and similar interests. Emory S. Bogardus in his book The Making of Public Opinion, 17 states that the public is the large number of people in which the source from one another may not know each other, but all have the same concern and interest to a problem. As well as the findings of the data in this study who will present some of the factors especially using SWOT analysis (strength, weak, opportunity, threat) [12]

Factors that affect the interests of the public in the junior high school Al-Aziziyah Sidoarjo at the start of the factors that support or in strength including the SWOT analysis in this school is the number of graduates who continue the education armed with enough religious knowledge recognized by the public.

Factors junior high school Al-Aziziyah weakness is the lack of the number of students with backgrounds that affect the budget of middle school fees. BOS funds are in accordance with the number of students in the school plus the additional funding contribution of each student is minimal yet meet all the needs of programs and activities in schools

Factors junior high school Al-Aziziyah opportunities are religious schools and with communities that have religious culture, this school is based on Islamic religious foundation that became the benchmark for all local residents. In accordance with the theory according to at.al Engel 18 points of which Environmental Factors [13].

Factors junior high school Al-Aziziyah threat is the behavior of some students who are less well be a reflection of the school so that negatively affect the image of the school. There are some children who received less attention and a good upbringing so that it can affect some other friends. This led to an interest in because of the public which, according to the negative image of the school, according to the theory Mappiare suggests that the shape of a person's interest is influenced by environmental background, economic level, social status, and experience .Solution of these obstacles in doing school apart cooperate with the public about guiding the student is tightened inside the school [14].

\section{CONCLUSION}

Based on the results of the discussion that has been described previously, it can be concluded that Planning public relations in an effort to attract people in the junior high school Al-Aziziyah Sidoarjo.

The planning process of public relations at Al-Aziziyah junior high school running communicative and democratic. Phase will be undertaken in the planning process by conducting meetings, analyze problems and needs, determine the form of formulation strategies / policies in the last completion and formulate media and techniques without forgetting the budget that is required in each program such public relations activities. The constraints in the face is the lack of participation of all the educators because of time constraints. Therefore, in the form a special team as a practitioner of public relations at the school.

Organizing public relations in an effort to attract people in the junior high school Al-Aziziyah Sidoarjo. Organizing public relations by focusing on special teams as delegation of public relations practitioners in schools. Besides organizing junior high school Al-Aziziyah also concerned with coordination, communication links, monitoring is done properly. The constraints of this organizing process are less to maximize the role of educators outside of special teams.

Implementation of public relations in an effort to attract people in the junior high school Al-Aziziyah Sidoarjo. The process of implementation of public relations at Al-Aziziyah junior high school run in accordance with formulations that have been planned together. Maximizing special team in the implementation of public relations to improve the performance of the implementation process in order to achieve common goals. Besides supervision by the principal and foundation leaders directly in its implementation. The constraints of the implementation process are the lack of teachers in the implementation of public relations programs and activities be less than the maximum. So, junior high school Al-Aziziyah utilize existing resources in overcoming obstacles that occur in the process of effective and efficient implementation. Implementation will increase public interest in the school.

Evaluation of public relations in an effort to attract people in the junior high school Al-Aziziyah Sidoarjo. The evaluation process of public relations at Al-Aziziyah junior high school Sidoarjo done through two stages: the formative evaluation and summative evaluation. Both formative and summative evaluation reports and program evaluation activities strive to provide advice or recommendations for further action.

Constraints on the evaluation process is the absence of the entire teaching staff in the evaluation meeting influence the outcome of the evaluation meeting. Therefore, junior high school Al-Aziziyah seek to enhance the role of educators as well as improve the communication channels to get the maximum results of the evaluation meeting.

Factors affecting the public interest in the junior high school Al-Aziziyah Sidoarjo. SWOT analysis is found in the junior high school Al-Aziziyah, among others: (1) power factor junior high school Al-Aziziyah is that many graduates who continue the education by armed religious knowledge sufficiently recognized by the public. (2) factors of weakness junior high school Al-Aziziyah is the minimal number of students with background medium that affect the budget of the school. (3) the chance junior high school Al-Aziziyah is faithbased schools with environment people who have a culture of religious education (4) factors junior high school Al-Aziziyah some students' behavior who are not well be a reflection of the school thus negatively affect the image of the school.

\section{ACKNOWLEDGMENT}

The article was prepared for the The 3rd International Conference on Education Innovation (ICEI) that is organized by Education Faculty, State University of Surabaya, Indonesia 24th Agustus 2019 in Surabaya, Indonesia. The author would 
like to thank the officer of Educational Management Study Program and Quality Assurance Group on Post Graduate State University of Surabaya. This publication reflects the views only of the author based on research.

\section{REFERENCES}

[1] J. Rapar, The Political Philosophy of Aristotle. Jakarta: PT Grafindo Persada, 1988.

[2] S. Yeo and A. Pang, "Asian Multiculturalism In Communication: The Impact Of Culture In The Practice Of Public Relations In Singapore," Public Relations Review, 2016.

[3] N. M. Ibrahim, "Assessment on the Condition of School Facilities: Case study of theselected public schools in Gombak district," Procedia: Social And Behavioral Sciences, vol. 222, pp. 228-234, 2016.

[4] M. Ragas, "Business 101 Education In Public Relations: An Exploratory Survey Senior Of Communication Executives," Public Relations Review, 2014.

[5] M. Andi, "Adolescent Psychology. Surabaya," National Business, 1982
[6] T. George R, Principles of Management. New York: Alexander Hamilton Institude, 2005.

[7] N. Ulfatin, Qualitative Research Methods in education: Theory and Application. Malang: MNC Publishing, 2015.

[8] Sutrisno, Assessing Philosophy of Education. Cirebon: Deepublish, 2014.

[9] Wilkinson, Gale, "Integrated management systems: an examination of the concept and theory ". The TQM Magazine Publishing, 1999.

[10] Johnson, Gerry and Calori, "Roland, CEOs' cognitive maps and the scope of the organization". Strategic Management Journal, vol. 15, pp. 437-457, 1994.

[11] Kunipuantari and Y. D and Suryono, "Effects of Cooperation Between Teachers And Parents Against Child Development Emotional Intelligence," Education And Empowerment Journal, vol. 1, pp. 18-31, 2014.

[12] K. Suhandang, Public Relations Company Nuance. Bandung, 2004.

[13] J. Engel, Consumer Behavior vol. 1. Jakarta: Binarupa Script, 1994.

[14] M. Andi, Adolescent Psychology. Surabaya: National Business, 1982. 